\title{
Differences in land use modify Odonata assemblages in the Cerrado-Caatinga ecotone
}

\author{
Diferenças no uso do solo modificam a estrutura das assembleias de Odonata (Insecta) \\ no ecótono Cerrado-Caatinga
}

\section{Daniel Silas Veras ${ }^{1 *}$ (D), Guilherme Santana Lustosa ${ }^{1}$ (D), Lucas Pereira Moura ${ }^{1}$ (D), Maria Fernanda Ribeiro Ferreira ${ }^{1}$ (D) and Leandro Juen ${ }^{2}$ (D)}

${ }^{1}$ Laboratório de Ecologia de Comunidades, Instituto Federal do Maranhão, Campus Caxias, Rodovia MA-340, Km 02, Gleba Buriti do Paraíso, Povoado Lamego, Zona Rural, CEP 65600-000, Caxias, MA, Brasil

${ }^{2}$ Laboratório de Ecologia e Conservação, Instituto de Ciências Biológicas, Universidade Federal do Pará, Rua Augusto Correia, nº 1, Bairro Guamá, CEP 66075-110, Belém, PA, Brasil *e-mail: daniel.veras@ifma.edu.br

Cite as: Veras, D.S. et al. Differences in land use modify Odonata assemblages in the Cerrado-Caatinga ecotone. Acta Limnologica Brasiliensia, 2020, vol. 32, e15.

Abstract: Aim: The present study tested the hypothesis that the composition of the odonate assemblages in environments with greater habitat integrity is significantly different from that of areas with reduced habitat integrity. Methods: The samples were collected between April 2017 and November 2017 in eight streams in Caxias, in the Brazilian state of Maranhão. The habitat integrity index was used to quantify habitat integrity. The odonate specimens were collected by the fixed area scanning method. Results: The habitat integrity index ranged from 0.265 to 0.915 at the different localities. A total of 229 specimens were collected, representing 19 odonate species. Species composition varied among streams that presented different degrees of conservation, with some species being typical of specific habitats. However, this variation had no effect on the number of taxa or the abundance of odonates, which may reflect the local substitution of extinct specialist species by generalists. Conclusions: Evidence indicates that the reduction of habitat integrity is an important predictor of changes in the biodiversity of aquatic insects in streams such as those of the Cerrado-Caatinga ecotone.

Keywords: dragonfly; damselfly; habitat integrity; riparian forest; streams.

Resumo: Objetivo: $\mathrm{O}$ presente estudo testou a hipótese de que a composição das assembleias de Odonata difere entre os riachos com maior integridade de habitat em relação aos de menor integridade. Métodos: As amostras foram coletadas entre abril de 2017 e novembro de 2017 no período de estiagem, em oito córregos em Caxias, Maranháo. O índice de integridade do habitat foi usado para quantificar a integridade do habitat. Os espécimes de Odonata foram coletados pelo método de varredura de área fixa. Resultados: $\mathrm{O}$ índice de integridade do habitat variou de 0,265 a 0,915 nos diferentes riachos. Um total de 229 espécimes foram coletados, representando 19 espécies Odonata. A composição das espécies variou entre os riachos que apresentaram diferentes graus de conservação, sendo que algumas espécies foram específicas para cada tipo de habitat. No entanto, esta variação não teve efeito sobre a riqueza de espécies ou a abundância de Odonata, o que pode refletir a substituição local de espécies especialistas por generalistas. Conclusóes: As evidências indicam que a redução da integridade do habitat é um importante preditor de mudanças na biodiversidade de insetos aquáticos em riachos como os do ecótono Cerra-Caatinga.

Palavras-chave: libélula; libelinha; integridade do habitat; floresta riparia; riacho. 


\section{Introduction}

In the tropics, the decrease in habitat integrity is an important driver of changes in the environmental quality of river basins, and this variable is correlated with the riparian forest loss (Veras et al., 2019; Carvalho et al., 2013a; Nessimian et al., 2008). By generating changes in the physical characteristics of the habitat, and the hydrology and quality of the water of rivers and streams, drastic changes in the aquatic biota cause a reduction of biological diversity in these ecosystems (Chen et al., 2017; Juen et al., 2016; Nessimian et al., 2008). This biodiversity loss threatens important ecosystems services, such as nutrient cycling, energy transfer along the food chain (Colas et al., 2017; Scott et al., 2012), and the self-purification of water, which guarantees the quality of this important resource.

Human activities that reduce or alter riparian forests and modify the physical structure of the habitat have a direct influence on the species richness and composition of a number of different groups of organisms (Cabette et al., 2017; Cunha \& Juen, 2017; Oliveira-Junior et al., 2017; Correa et al., 2015). In this context, the use of sentinel organisms or bioindicators of environmental quality (Ghannem et al., 2018; Shaiek et al., 2018; Galindo-Pérez et al., 2017), such as insects of the order Odonata, is essential for the assessment of environmental impacts and the prioritization of conservation areas (Miguel et al., 2017; Nóbrega \& De Marco Junior, 2011).

In the world, the order Odonata is subdivided into three suborders Anisoptera, Zygoptera and Anisozygoptera and in the Neotropical region only the first two occur which have distinct ecophysiological requirements for thermoregulation (De Marco Junior et al., 2015; Miguel et al., 2017; Carvalho et al., 2013a; Trueman \& Rowe, 2009). Anisopterans usually have medium to large bodies and regulate body temperature either endothermically using the heat produced by the muscles of the wings, ectothermically (heliothermic forms) or by thermal shaping (May, 1976). The zygopterans, by contrast, are small to medium sized, and regulate body temperature mainly by ectothermic mechanisms, that is, by changing the heat of their body in response to the ambient temperature (De Marco Junior et al., 2015). Because of these ecophysiological differences, the structure of the community may be altered in relation to pristine environments, that decrease their shading areas. Thus, Anisoptera and Zygoptera are very useful as bioindicators, assessing the impact of habitat degradation on aquatic fauna (De Marco Junior et al., 2015; Miguel et al., 2017).

Therefore, with increasing human pressure on tropical ecosystems, it is necessary to evaluate and monitor how differences in land use and landscape influence the biological diversity of these environments (Oliver et al., 2016; Newbold et al., 2015). One analytical strategy is the use of indices to quantify the effects of land use on environmental conditions (Peck et al., 2002; Kaufmann et al., 1999; Karr et al., 1986). The Habitat Integrity Index (HIII), formulated by Nessimian et al. (2008), is a metric that assesses the influence of land use and occupation on the water quality of streams within the drainage basin (Veras et al., 2019) and has been widely used in ecological assessments (Brasil et al., 2014; Carvalho et al., 2013b; Pereira et al., 2012; Souza et al., 2011).

Several ecological studies have been carried out with Odonata in Amazon biomes (Chen et al.,

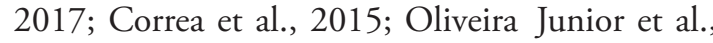
2015; Couceiro et al., 2007), there are also several others for the Cerrado (Cabette et al., 2017; Brasil et al., 2014; Juen et al., 2014), however, for the Cerrado-Caatinga ecotone there are large Hutchinsonian, Linnean and Wallacean gaps (Bastos et al., 2019; De Marco \& Vianna, 2005). Thus, in the present study, we tested the hypothesis that the odonate assemblages of environments with higher habitat integrity have distinct species richness, composition, and abundance in comparison with areas that have lower habitat integrity. As more conserved areas are characterized by greater environmental heterogeneity, they should have more specialist species, whereas areas with reduced habitat integrity will tend to have more generalist species (De Marco Junior et al., 2015; Juen, 2006).

\section{Materials and Methods}

\subsection{Study area}

The study was conducted in the municipality of Caxias, Maranhão (Brazil), which has an area of $531,350 \mathrm{ha}$, and is located in the eastern extreme of the state (Table 1) (Fernandes et al., 2010). The climate is hot and humid equatorial with maximum temperature of $38.3{ }^{\circ} \mathrm{C}$, minimum of $21.2^{\circ} \mathrm{C}$, and annual rainfall of $1200-1300 \mathrm{~mm}$. The region has two well-defined seasons, a rainy season that coincides with the austral autumn and a dry season in the austral spring (Siqueira $\&$ Henry-Silva, 2011). The region is a Cerrado-Caatinga ecotone, whose predominant phytophysiognomy is seasonal deciduous forest (Lima et al., 2016), also 
Table 1. Odonate species collected in the streams sampled in the municipality of Caxias, Maranhão (Brazil).

\begin{tabular}{lccccccccc}
\hline \multicolumn{1}{c}{ Riachos } & Inhamum & Soledade & Sumidouro & $\begin{array}{c}\text { Areia } \\
\text { Branca }\end{array}$ & Lamego & $\begin{array}{c}\text { São } \\
\text { José }\end{array}$ & Sanharó & Cocos & Mean \\
\hline Depth $(\mathrm{cm})$ & 75 & 97 & 88 & 68 & 18 & 19 & 25 & 25 & 51.875 \\
Wipth $(\mathrm{cm})$ & 191 & 274 & 149 & 134 & 124 & 319 & 193 & 150 & 191.75 \\
Velocity $(\mathrm{cm} / \mathrm{s})$ & 0.29 & 0,37 & 0.35 & 0.35 & 0.11 & 0.22 & 0.26 & 0 & 0.244 \\
Discharge(m3/s) & 0.42 & 0.98 & 0.46 & 0.32 & 0.02 & 0.16 & 0.14 & 0 & 0.313 \\
IIH & 0.887 & 0.915 & 0.915 & 0.811 & 0.303 & 0.316 & 0.684 & 0.265 & 0.637 \\
Coordenadas & $\mathrm{X}:-43,5853$ & $-43,4628$ & $-43,5619$ & $-43,4858$ & $-43,4386$ & $-43,3997$ & $-43,4642$ & $-43,4417$ & \\
& $\mathrm{y}:-5,0367$ & $-5,0075$ & $-4,9614$ & $-5,0372$ & $-5,1375$ & $-4,9019$ & $-4,8972$ & $-4,9236$ & \\
\hline
\end{tabular}

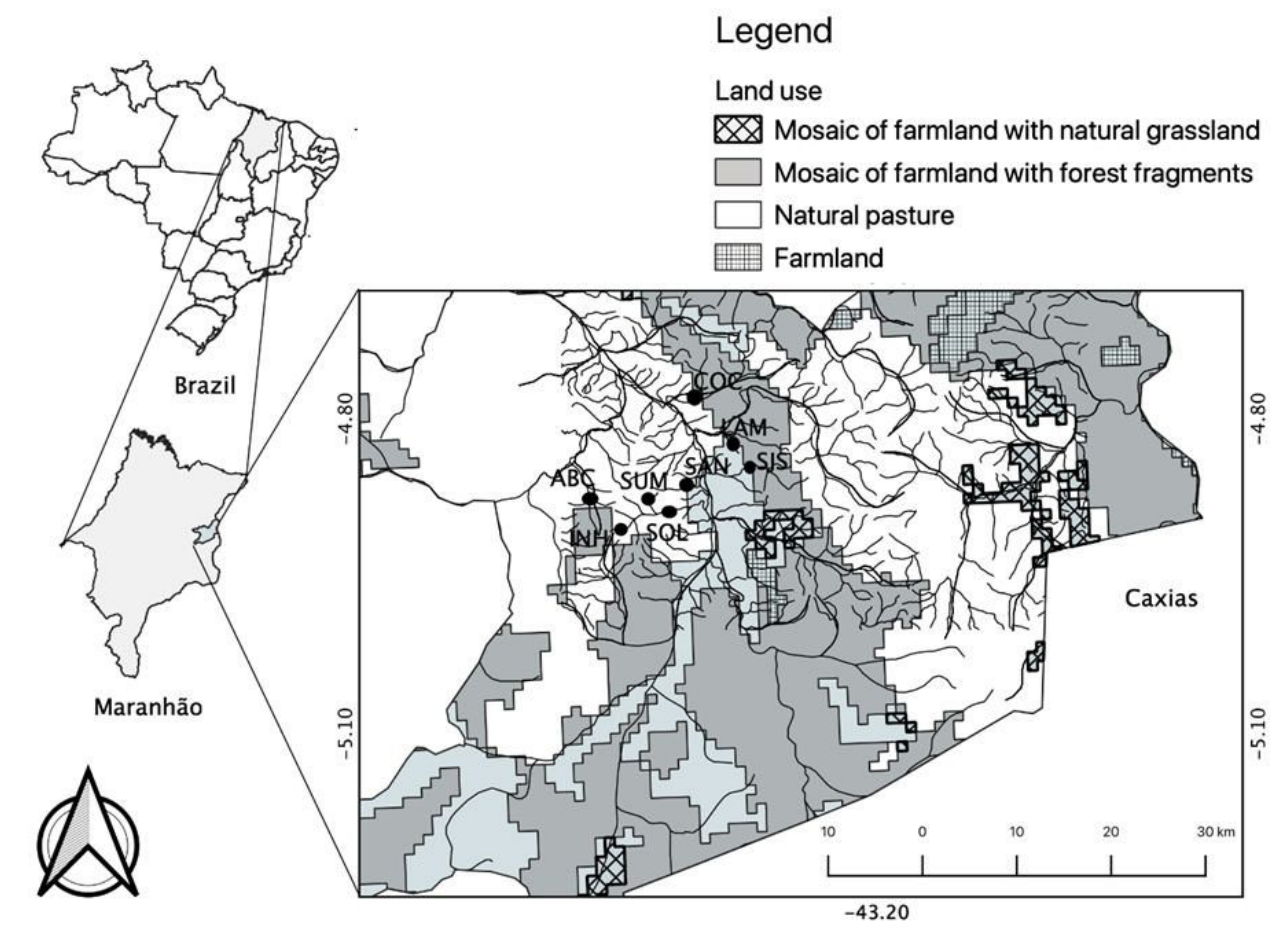

Figure 1. Samples units (streams) of the Itapecuru basin in the municipality of Caxias, Maranháo (Brazil) in the present study. Streams: Areia Branca (ABC), Cocos (COC), Inhamum (INH), Lamego (LAM), São José (SJS), Sanharó (SAN), Soledade (SOL), Sumidouro (SUM).

features rural landscape, savanna and seasonal tropical scleromorphic and semideciduous forests (Correia Filho et al., 2011). The principal land use is agriculture, while urbanization expanded significantly from the 1990 s onwards (Neto, 2015; Silva \& Conceição, 2011). The streams in this study vary in depth from 18 to $97 \mathrm{~cm}$ $(51,875 \pm 33,399 \mathrm{~cm})$, the width varied from 124 to $319 \mathrm{~cm}(152,274 \pm 76,857 \mathrm{~cm})$, with speed between 0 to $0.37 \mathrm{~cm} / \mathrm{s},(0.244 \pm 0.130)$ and flow rate ranging from 0 to $0.98 \mathrm{~m}^{3} / \mathrm{s}\left(0.313 \pm 0.320 \mathrm{~m}^{3} / \mathrm{s}\right)$ (Veras et al., 2019).

\subsection{Data collection}

Samples were collected between April 2017 and November 2017 (dry season) at eight first to third order streams, based on Strahler (1957) classification, in different land use, based in IBGE Land Coverage and Use Map of Brazil (IBGE, 2016). Each stream was visited once during the study period, this period that shows greatest stability of the climate conditions of the region and of the physical and chemical conditions of the river basin (Figure 1).

The scanning in fixed areas technique, which has been used successfully in previous studies (Juen \& De Marco, 2011), was used for the collection of adult odonates, which were captured in an entomological net. At each stream, a 100-meter stretch was divided into 205 -m segments, with each segments being sampled for an average of one hour. The 20 segments sampled in each stream are pseudoreplicates designed to estimate species richness reliably and increase the efficiency of the 
sampling protocol. Each stream was considered a sample unit for the analyses. As the research question was spatial, and not temporal, a total of eight samples were collected (Juen et al., 2014).

The HII was applied in the same stretches in which the odonates were sampled, this index is composed of 12 items, with 4-6 alternatives that represent different environmental conditions found in both the stream bed and the area adjacent to it. The index generated from these scores varies from zero (most degraded) to one, i.e., most conserved and is provided by the mean value of these scores relative to the number of items analyzed (Juen et al., 2014; Carvalho et al., 2013b; Nessimian et al., 2008).

The collection and conservation of the specimens followed the recommendations of Lencioni (2006), and taxonomic keys (Garrison, 2010; Garrison et al., 2006; Heckman, 2006; Lencioni 2005,2006 ), were used to identify the species and morphospecies.

\subsection{Data Analysis}

To determine the sample sufficiency of the study, we built a species accumulation curve, for that, we used the first order non-parametric richness estimate Jackknife. This method estimates the variability in the data set by systematically excluding each observation and recalculating the statistic (Gotelli \& Ellison, 2016), based on the number of unique species (which occurred in only a single sample). The collection efficiency was determined through the quotient between the value of the species richness observed by the estimated species richness. (Gotelli \& Colwell, 2011).

To estimate the variation in species composition among the samples, a Principal Coordinates Analysis (PCoA) was applied to a Bray-Curtis matrix, following the $\log (x+1)$ transformation of the abundance data. The PERMANOVA was carried out based on the Bray-Curtis dissimilarity to evaluate species composition between high HII values ( $>0.8$; conserved) and low HII values $(<0.7$; altered) streams using 9.999 permutations.

A gradient analysis was used to construct a composite plot (Landeiro et al., 2010) of the distribution of the odonate community along the anthropogenic habitat gradient. A simple linear regression was used to assess whether habitat integrity explained species richness. The estimates of species richness was computed in EstimateS 7 (Colwell et al., 2004) and the other statistical analyzes were performed using vegan package of the R 3.2.2 statistical environment (R Foundation for Statistical Computing, 2015).

\section{Results}

The HII scores of the study streams ranged from 0.265 to 0.915 (mean \pm standard deviation: $0.637 \pm 0.293$ ), the preserved streams, with higher HII values, present riparian forest with continuous forest composed of native trees and few breaks in the riverside area. While the altered ones, lower HII values, have as main characteristic frequent breaks in the riparian zone, absence or continuous strip of forest below 30 meters, presence of ravines, effluent discharge and widening due to the accumulation of sediments (Table 1).

A total of 229 odonate specimens were collected, although it was possible to identify only 191, given that 30 were females, and in most species descriptions, the description of the female is incomplete or absent, meaning that, in most cases, they can only be identified when captured in tandem.

Most specimens (115) belong to the suborder Zygoptera, with the other 76 being anisopterans. Argia (four species) was the most species-rich genus, followed by Erytrhodiplax, with three species. The $83 \%$ collection efficiency indicated that the sampling procedure was sufficient to capture the biodiversity existing in the study area, given the stabilization of the species accumulation curve. In addition, observed species richness was $19 \pm 1.81$, while estimated richness was $22.98 \pm 1.97$. The most abundant species were Acanthagrion aepiolum ( $\mathrm{n}=46$ individuals) followed by Zenithoptera lanei, with 22 individuals (Table 2).

The species composition of the different streams was allocated to two distinct groups (PERMANOVA, pseudo- $\mathrm{F}_{(1,7)=} 4.674, \mathrm{p}=0.024$ (Figure 2), indicating that habitat integrity affects the composition of odonate species. Clearly, there are species that are typical of environments with high environmental integrity. However, the hypotheses that habitat integrity affects Anisoptera species richness $(\mathrm{r} 2=0.017 ; \mathrm{p}=0.756)$ or abundance $(\mathrm{r} 2=0.080 ; \mathrm{p}=0.497)$, and Zygoptera species richness $(\mathrm{r} 2=0.032 ; \mathrm{p}=0.668)$ or abundance $(\mathrm{r} 2=0.056 ; \mathrm{p}=0.572)$ were not supported.

Only six of the 19 species identified were common to all types of stream. Five species (A. aepiolum, A. gracile, $H$. auripennis, T. aurantinigrum, and T. coccinea) were unique to streams with a HII below 0.7 . Eight species (A. hasermani, A. indicatrix, A. lilacina, E. metallica, E. melanica, Hetaerina sp., 
Table 2. Odonate species collected in the streams sampled in the municipality of Caxias, Maranhão (Brazil).

\begin{tabular}{|c|c|c|c|c|c|c|c|c|}
\hline \multirow[b]{2}{*}{ Species } & \multicolumn{8}{|c|}{ Riachos } \\
\hline & 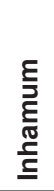 & $\begin{array}{l}\frac{0}{0} \\
\frac{\pi}{0} \\
\frac{0}{0} \\
\text { க }\end{array}$ & $\begin{array}{l}\text { 을 } \\
\frac{0}{0} \\
\frac{0}{E} \\
\frac{5}{5} \\
\text { ค }\end{array}$ & $\begin{array}{l}\mathbb{U} \\
\frac{0}{\pi} \\
\frac{\pi}{0} \\
\frac{\pi}{0} \\
\frac{0}{0}\end{array}$ & 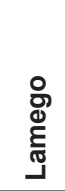 & 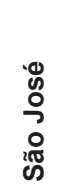 & $\begin{array}{l}\frac{0}{\frac{0}{\pi}} \\
\frac{c}{\frac{1}{L}} \\
\text { స్ }\end{array}$ & $\begin{array}{l}\text { O̊ } \\
\text { O } \\
0\end{array}$ \\
\hline Acanthagrion gracile (Rambur, 1842) & 0 & 0 & 0 & 0 & 3 & 3 & 4 & 4 \\
\hline Acanthagrion aeopilum Tennessen, 2004 & 0 & 0 & 0 & 0 & 8 & 32 & 4 & 2 \\
\hline Argia hasemani Calvert 1909 & 0 & 6 & 0 & 1 & 0 & 0 & 0 & 0 \\
\hline Argia indicatrix Calvert, 1901 & 0 & 5 & 0 & 1 & 0 & 0 & 0 & 0 \\
\hline Argia lilacina Selys, 1865 & 0 & 0 & 1 & 0 & 0 & 0 & 0 & 0 \\
\hline Argia reclusa Selys, 1865 & 0 & 4 & 2 & 5 & 4 & 4 & 0 & 0 \\
\hline Diastatops obscura (Fabricius, 1775) & 2 & 0 & 0 & 0 & 3 & 0 & 0 & 2 \\
\hline Epipleoneura metallica Rácenis, 1955 & 0 & 4 & 6 & 0 & 0 & 0 & 0 & 0 \\
\hline Erythrodiplax basalis (Kirby, 1897) & 2 & 0 & 0 & 1 & 3 & 0 & 2 & 9 \\
\hline Erythrodiplax fusca (Rambur, 1842) & 1 & 0 & 2 & 0 & 3 & 0 & 1 & 6 \\
\hline Erythrodipla melanica Borror, 1942 & 3 & 1 & 0 & 1 & 0 & 0 & 0 & 0 \\
\hline Hetaerina sp. & 1 & 0 & 0 & 0 & 0 & 0 & 0 & 0 \\
\hline Hetaerina auripennis (Burmeister, 1839) & 0 & 0 & 0 & 0 & 0 & 2 & 0 & 0 \\
\hline Micrathyria romani Sjöstedt, 1918 & 0 & 0 & 1 & 0 & 0 & 0 & 0 & 0 \\
\hline Orthemis biolleyi Calvert, 1906 & 0 & 0 & 1 & 0 & 0 & 0 & 0 & 0 \\
\hline Perithemis lais (Perty, 1834) & 0 & 0 & 2 & 0 & 8 & 0 & 0 & 0 \\
\hline Telebasis coccinea (Selys, 1876) & 0 & 0 & 0 & 0 & 0 & 3 & 0 & 0 \\
\hline Tigriagrion aurantinigrum Calvert, 1909 & 0 & 0 & 0 & 0 & 0 & 6 & 0 & 0 \\
\hline Zenithoptera lanei Santos, 1941 & 7 & 1 & 6 & 5 & 1 & 0 & 0 & 2 \\
\hline Abundance & 16 & 21 & 21 & 14 & 33 & 50 & 11 & 25 \\
\hline Observed richness & 6 & 6 & 8 & 6 & 8 & 6 & 4 & 6 \\
\hline
\end{tabular}

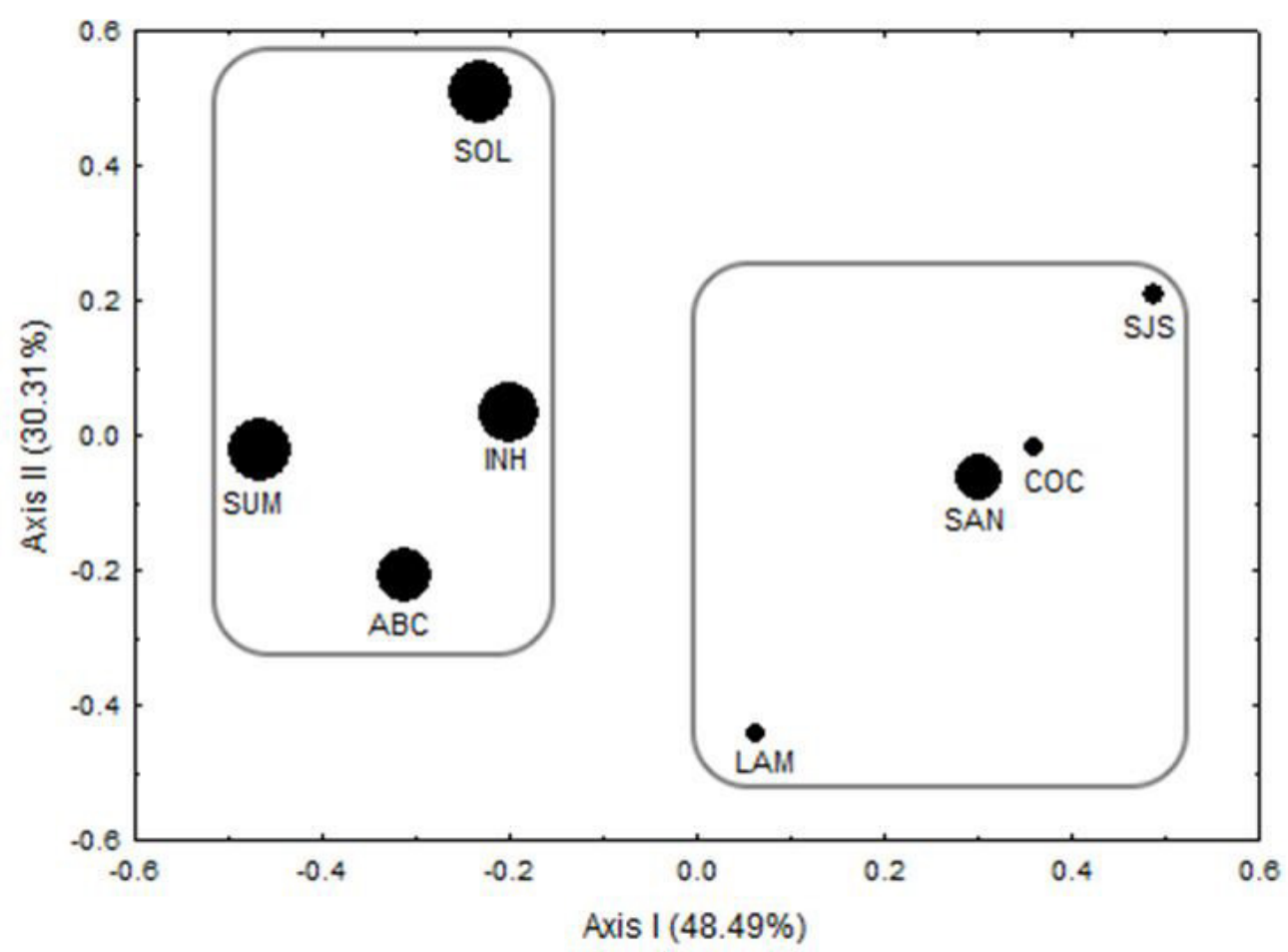

Figure 2. Ordination of the composition of odonate species from the streams of Caxias, Maranhão, Brazil, based on a Principal Coordinate Analysis (PCoA). The size of the points represents the value of the Habitat Integrity Index. Streams: Areia Branca (ABC), Cocos (COC), Inhamum (INH), Lamego (LAM), São José (SJS), Sanharó (SAN), Soledade (SOL), Sumidouro (SUM). 


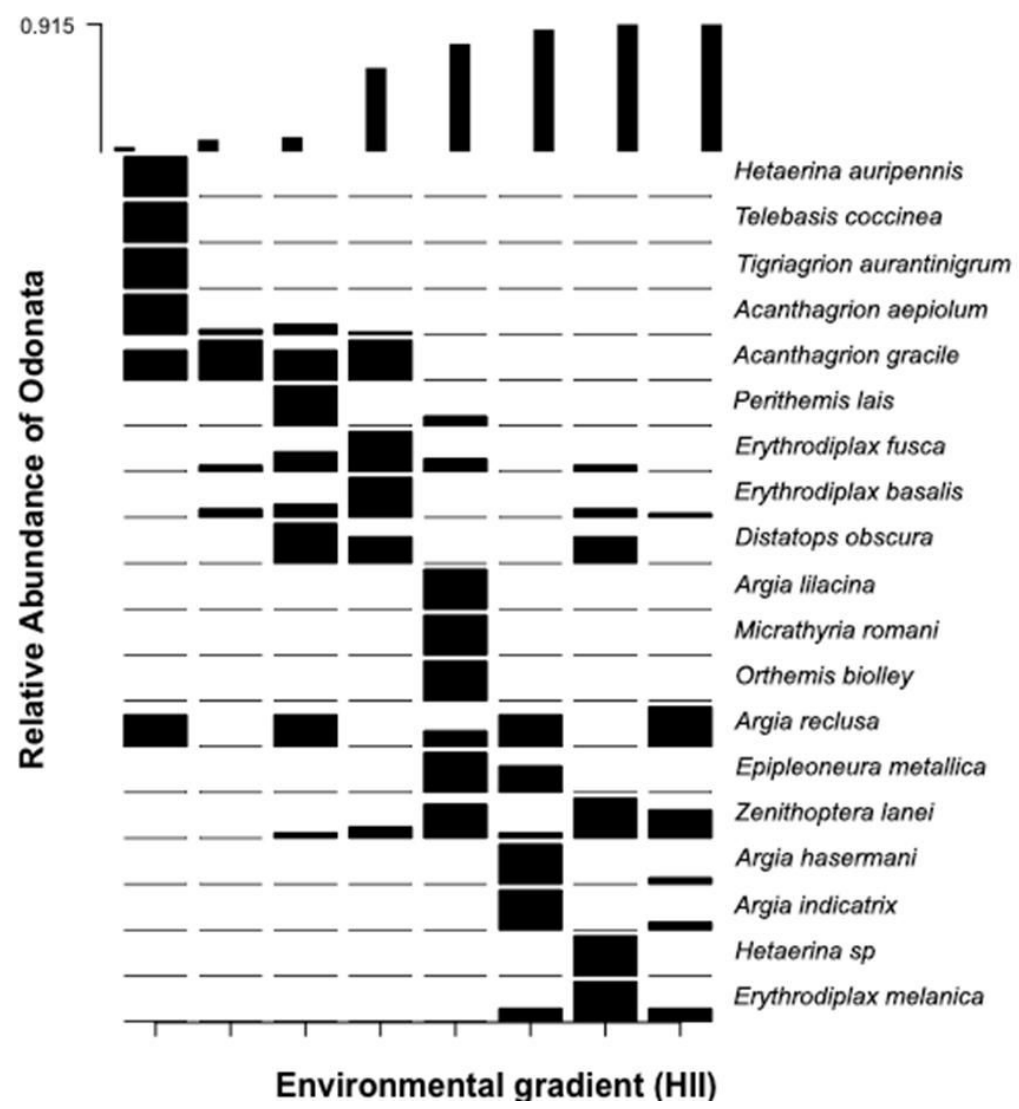

Figure 3. Distribution of the odonate community along the anthropogenic habitat gradient in the streams of Caxias, Maranhão, Brazil.

M. romani, and $O$. biolley) were unique to streams with a HII above 0.8 . This reflects the variation in the distribution of the odonate community along the habitat gradient (Figure 3).

\section{Discussion}

The environmental integrity of the stream did not affect the species richness or abundance of odonates, although there was a clear influence on species composition, with degraded and conserved streams being clearly separated. This is consistent with previous studies that indicate that the environmental gradient, in particular the loss of riparian vegetation, determines systematic variation in the composition of odonate species (Calvão et al., 2016; Carvalho et al., 2013a), given the contrasting ecophysiological requirements of the two suborders (Anisoptera and Zygoptera) for thermoregulation (De Marco Junior et al., 2015).

Studies carried out in Amazon region show that the abundance and richness of Odonata is affected by the characteristics of the environment, with the width of the channel being one of the main factors that influence the assembly of the community (De Marco Junior et al., 2015; Monteiro Júnior et al., 2015), there is also a decrease in richness in areas impacted by urbanization (Monteiro-Júnior et al., 2014). In contrast, our results show only a substitution of species associated with healthy environments for others typical of anthropized places, even some individuals belonging to the suborder Zygoptera (Craves \& O'Brien, 2013; Goertzen \& Suhling, 2013).

The lack of any systematic variation in species richness or abundance may have been due to the species substitution, that typically occurs following the modification of environments. While more specialist species are typically eliminated from degraded environments, species richness and abundance may remain constant through the arrival of more generalist species that are less sensitive to environmental change. For example, many species are able to colonize sites with altered environmental conditions (Oliveira-Junior et al., 2017), and may be widely distributed (Anjos-Santos et al., 2011; Pessacq et al., 2005). Given this, they can adapt to a variety of habitat types, and are disperse between fragments or even colonize open areas (Rodrigues et al., 2016). 
The shift in species composition related to environmental change can be explained by the relative participation of rare and sensitive species. In general, thermal shapers are replaced by species with generalist and opportunistic individuals, that are typically heliothermic or endothermic (Miguel et al., 2017; De Marco Junior et al., 2015). In this case, species of the genus Argia, which are diverse and widely distributed in the Neotropical region, can be lost (Calvão et al., 2014; Caesar $\&$ Wenzel, 2009). In this context, many species restricted to more conserved areas can be lost through habitat degradation, creating a significant threat to the regional pool of species. This indicates that changes in land use (e. g. farming, urban development) is one of the principal threats to biodiversity (Phillips et al., 2017).

The results of the present study are consistent with the findings of previous research, which indicates that changes in habitat integrity are mainly due to the removal of the vegetation cover on the margins of the streams (Monteiro-Júnior et al., 2015; Carvalho et al., 2013a). This leads to shifts in the conditions and resources available in the body of water (Callisto et al., 2001), which are important drivers of the structure of aquatic communities, while tending to maintain a greater similarity with the composition of species found in forested areas (Juen et al., 2016).

None of the species collected during the present study are at any risk of extinction, according to the classification of the Brazilian Chico Mendes Institute for Conservation and Biodiversity (ICMBio, 2016). Unlike expected, the occurrence of species of the suborder Zygoptera (A. aepiolum, $H$. auripennis, T. coccinea and T. aurantinigrum), were restricted to altered streams, indicating ecological diversity within the suborder, a pattern observed in other studies (Bastos et al., 2019; Rodrigues et al., 2019, 2016; Carvalho et al., 2013a; Monteiro Júnior et al., 2013; Kalkman et al., 2007). This occurs because $A$. aepiolium, $A$. gracile, $H$. auripennis present the epiphytic type of oviposition, laying their eggs on the macrophytes (Rodrigues et al., 2018; Kompier, 2015), thus, areas without riparian vegetation and that develop a greater amount of aquatic macrophytes are the perfect habitats for these species (Rodrigues et al., 2018; Vilela et al., 2016). While, T. aurantinigrum has underwater endophytic oviposition, requiring less speed of flow (wide and shallow streams) for occurring the oviposition and survival of the larvae. (De Marco Junior \& Vital, 2008).
In the streams considered conserved, Zygoptera species was the main occurrence (A. hasermani, A. indictrix, Hetaerina sp 1), as expected, considering that species of this suborder have great fidelity and specificity for preserved environments (Monteiro-Junior et al., 2015, 2014). The presence of an species of Anisoptera (E. melanica) was also observed, several species of the genus Erythrodiplax are generalists (Rodrigues et al., 2018; Mendes et al., 2015), in this sense, this species can occur in an environmental continuum that varies from the degraded to the conserved environment (Cortês et al., 2011).

Overall, the species composition of preserved and altered streams was quite distinct, even though no variation was observed in the species richness of the two suborders. These findings emphasize the need for the assessment of how the integrity of the riparian forest and other physical-chemical variables influence the community structure of the immature taxa and how this influences the structure of the adult assemblage. In addition, we confirmed that the reduction of the habitat integrity is the driver of changes in the structure of the Odonata communities of tropical regions, reinforcing the need for government agencies to monitor properties more systematically, and enforce the legislation on forest management.

\section{References}

ANJOS-SANTOS, D., CARRIÇO, C., COSTA, J.M. and SANTOS, T.C. Description of the final instar larvae of Acanthagrion gracile (Rambur) and Acanthagrion lancea Selys (Odonata: Coenagrionidae). Zootaxa, 2011, 2832(1), 44-50. http://dx.doi. org/10.11646/zootaxa.2832.1.2.

BASTOS, R.C., BRASIL, L.S., CARVALHO, F.G., CALVÃO, L.B., SILVA, J.O.A. and JUEN, L. Odonata of the state of Maranhão, Brazil: Wallacean shortfall and priority areas for faunistic inventories. Biota Neotropica, 2019, 19(4), 1-11. http://dx.doi. org/10.1590/1676-0611-bn-2019-0734.

BRASIL, L.S., JUEN, L. and CABETTE, H.S.R. The effects of environmental integrity on the diversity of mayflies, Leptophlebiidae (Ephemeroptera), in tropical streams of the Brazilian Cerrado. Annales de Limnologie-International Journal of Limnology, 2014, 50(4), 325-334. http://dx.doi.org/10.1051/ $\operatorname{limn} / 2014026$.

CABETTE, H.S.R., SOUZA, J.R., SHIMANO, Y. and JUEN, L. Effects of changes in the riparian forest on the butterfly community (Insecta: Lepidoptera) in Cerrado areas. Revista Brasileira de Entomologia, 2017, 61(1), 43-50. http://dx.doi.org/10.1016/j. rbe.2016.10.004. 
CAESAR, R.M. and WENZEL, J.W. A phylogenetic test of classical species groups in Argia (Odonata: Coenagrionidae). Entomologica Americana, 2009, 115(2), 97-108. http://dx.doi.org/10.1664/09RA-001.1.

CALLISTO, M., MORETTI, M. and GOULART, M. Macroinvertebrados bentônicos como ferramenta para avaliar a saúde de riachos. Revista Brasileira de Recursos Hidricos, 2001, 6(1), 71-82. http://dx.doi. org/10.21168/rbrh.v6n1.p71-82.

CALVÃO, L.B., DE MARCO, P. and BATISTA, J.D. Odonata (Insecta) from Nova Xavantina, Mato Grosso, Central Brazil: Information on species distribution and new records. Check List, 2014, 10(2), 299-307. http://dx.doi.org/10.15560/10.2.299.

CALVÃO, L.B., NOGUEIRA, D.S., DE ASSIS MONTAG, L.F., LOPES, M.A. and JUEN, L. Are Odonata communities impacted by conventional or reduced impact logging? Forest Ecology and Management, 2016, 382, 143-150. http://dx.doi. org/10.1016/j.foreco.2016.10.013.

CARVAlHO, F.G., DE OliVEIRA, J.M.B., DE FARIAS, A.P.J. and JUEN, L. Use of the ABC curve as a method to detect the effect of anthropogenic change on the Odonata (Insecta) Assembly. Interciencia, 2013b, 38(7), 516-522.

CARVALHO, F.G., PINTO, N.S., OLIVEIRA JÚNIOR, J.M.B., and JUEN, L. Effects of marginal vegetation removal on Odonata communities. Acta Limnologica Brasiliensia, 2013a, 25(1), 10-18. https:// doi.org/10.1590/S2179-975X2013005000013

CHEN, K., HUGHES, R.M., BRITO, J.G., LEAL, C.G., LEITÃO, R.P., DE OLIVEIRA-JÚNIOR, J.M.B., DE OLIVEIRA, V.C., DIAS-SILVA, K., FERRAZ, S.F.B., FERREIRA, J., HAMADA, N., JUEN, L., NESSIMIAN, J., POMPEU, P.S. and ZUANON, J. A multi-assemblage, multi-metric biological condition index for eastern Amazonia streams. Ecological Indicators, 2017, 78, 48-61. http:// dx.doi.org/10.1016/j.ecolind.2017.03.003.

COLAS, F., BAUDOIN, J.M., GOB, F., TAMISIER, V., VALETTE, L., KREUTZENBERGER, K., LAMBRIGOT, D. and CHAUVET, E. Scale dependency in the hydromorphological control of a stream ecosystem functioning. Water Research, 2017, 115, 60-73. http://dx.doi.org/10.1016/j. watres.2017.01.061. PMid:28259815.

COLWELL, R.K., MAO, C.X. and CHANG, J. Interpolating, extrapolating, and comparing incidence区based species accumulation curves. Ecology, 2004, 85(10), 2717-2727. http://dx.doi. org/10.1890/03-0557.

CORREA, F.S., JUEN, L., RODRIGUES, L.C., SILVA-FILHO, H.F. and SANTOS-COSTA, M.C. Effects of oil palm plantations on anuran diversity in the eastern Amazon. Animal Biology (Leiden,
Netherlands), 2015, 65(3-4), 321-335. http://dx.doi. org/10.1163/15707563-00002481.

CORREIA FILHO, F.L., GOMES, É.R., NUNES, O.O. and LOPES FILHO, J.B. Projeto cadastro de fontes de abastecimento por água subterrânea: estado do Maranhão: relatório diagnóstico do município de Caxias. Teresina: CPRM, 2011.

CÔRTES, L.G., DE ALMEIDA, M.C., PINTO, N.S. and DE MARCO-JÚNIOR, P. Fogo em Veredas: Avaliação de impactos sobre comunidades de Odonata (Insecta). Biodiversidade Brasileira, 2011, 2, 128-145.

COUCEIRO, S.R.M., HAMADA, N., LUZ, S.L.B., FORSBERG, B.R. and PIMENTEL, T.P. Deforestation and sewage effects on aquatic macroinvertebrates in urban streams in Manaus, Amazonas, Brazil. Hydrobiologia, 2007, 575(1), 271284. http://dx.doi.org/10.1007/s10750-006-0373-z.

CRAVES, J.A. and O'BRIEN, D.S. The Odonata of Wayne County, MI: Inspiration for renewed monitoring of urban areas. Northeastern Naturalist, 2013, 20(2), 341-362. http://dx.doi. org/10.1656/045.020.0210.

CUNHA, E.J. and JUEN, L. Impacts of oil palm plantations on changes in environmental heterogeneity and Heteroptera (Gerromorpha and Nepomorpha) diversity. Journal of Insect Conservation, 2017, 21(1), 111-119. http://dx.doi.org/10.1007/ s10841-017-9959-1.

DE MARCO JUNIOR, P. and VITAL, M.V.C. Ecology of Tigriagrion aurantinigrum Calvert in response to variations in environmental conditions (Zygoptera: Coenagrionidae). Odonatologica, 2008, 37(1), 1-11.

DE MARCO JUNIOR, P., BATISTA, J.D. and CABETTE, H.S.R. Community assembly of adult odonates in tropical streams: an ecophysiological hypothesis. PLoS One, 2015, 10(4), 1-17. http:// dx.doi.org/10.1371/journal.pone.0123023. PMid:25906243.

DE MARCO, P. and VIANNA, D.M. Distribuição do esforço de coleta de Odonata no Brasil: subsídios para escolha de áreas prioritárias para levantamentos faunísticos. Lundiana, 2005, 6(1), 13-26.

FERNANDES, R.S., CONCEIÇÃO, G.M., COSTA, J.M. and PAULA-ZÁRATE, E.L. Samambaias e licófitas do município de Caxias, Maranhão, Brasil. Boletim do Museu Paraense Emílio Goeldi, 2010, 5(3), 345-356.

GALINDO-PÉREZ, E.J., CHÁVEZ-SANDOVAL, B.E., ESPINOZA-GRACIANO, E., DEL CARMEN FLORES-MARTÍNEZ, M., DEL PILAR VILLEDA-CALLEJAS, M., BHALLI, J.A., TEJOCOTE-PÉREZ, M. and GARCÍA-FRANCO, F. Cave macroinvertebrates as bioindicators of water quality. IMTA-TC, 2017, 8(5), 5-17. http://dx.doi. org/10.24850/j-tyca-2017-05-01. 
GARRISON, R.W. Damselfly genera of the new worldan illustrated and annotated key to the Zygoptera. Baltimore: The Johns Hopkins University Press, 2010.

GARRISON, R.W., VON ELLENRIEDER, N. and LOUTON, J.A. Dragonfly genera of the New World: an illustrated and annotated key to the Anisoptera. Baltimore: JHU Press, 2006.

GHANNEM, S., TOUAYLIA, S. and BOUMAIZA, M. Beetles (Insecta: Coleoptera) as bioindicators of the assessment of environmental pollution. Human and Ecological Risk Assessment, 2018, 24(2), 456464. http://dx.doi.org/10.1080/10807039.2017.1 385387.

GOERTZEN, D. and SUHLING, F. Promoting dragonfly diversity in cities: major determinants and implications for urban pond design. Journal of Insect Conservation, 2013, 17(2), 399-409.

GOTELLI, N. J., and COLWELL, R. K. Estimating species richness. In: A.E. MAGURRAN and J.B. MCGILL. Biological diversity: frontiers in measurement and assessment. Vol. 12. Oxford, New York: Oxford University Press, 2011, pp. 39-54.

GOTElli, N.J. and ELliSON, A.M. Principios de estatística em ecologia. Porto Alegre: Artmed Editora, 2016.

HECKMAN, C.W. Encyclopedia of South American aquatic insects: Odonata-Anisoptera: illustrated keys to known families, genera, and species in South America. Washington: Springer Science \& Business Media, 2006.

INSTITUTO BRASILEIRO DE GEOGRAFIA E ESTATÍSTICA - IBGE. Monitoramento da cobertura e uso da terra do Brasil [online]. Rio de Janeiro: IBGE, 2016 [viewed 19 Oct. 2019]. Available from: https:// www.ibge.gov.br/apps/monitoramento_cobertura uso_terra/v1/

INSTITUTOCHICO MENDES DE CONSERVAÇÃO DA BIODIVERSIDADE - ICMBio. Sumário Executivo do Livro Vermelho da Fauna Brasileira Ameaçada de Extinção. Brasília: Ministério do Meio Ambiente, 2016, pp. 1-76. https://doi. org/10.1089/1549541041438560

JUEN, L. Distribution of Odonata species and the beta diversity pattern found among streams in Central Amazonia [Dissertação de Mestrado]. Viçosa: Universidade Federal de Viçosa, 2006.

JUEN, L., and DE MARCO, P. (2011). Odonate biodiversity in terra-firme forest streamlets in Central Amazonia: on the relative effects of neutral and niche drivers at small geographical extents. Insect Conservation and Diversity, 4(4), 265-274. https:// doi.org/10.1111/j.1752-4598.2010.00130.x

JUEN, L., CUNHA, E.J., CARVAlHO, F.G., FERREIRA, M.C., BEGOT, T.O., ANDRADE, A.L., SHIMANO, Y., LEÃO, H., POMPEU,
P.S. and MONTAG, L.F.A. Effects of oil palm plantations on the habitat structure and biota of streams in Eastern Amazon. River Research and Applications, 2016, 32(10), 2081-2094. http:// dx.doi.org/10.1002/rra.3050.

JUEN, L., OLIVEIRA-JUNIOR, J.M.B., SHIMANO, Y., MENDES, T.P. and CABETTE, H.S.R. Composição e riqueza de Odonata (Insecta) em riachos com diferentes níveis de conservação em um ecótone Cerrado-Floresta Amazônica. Acta Amazonica, 2014, 44(2), 223-233. http://dx.doi. org/10.1590/S0044-59672014000200008.

KALKMAN, V.J., CLAUSNITZER, V., DIJKSTRA, K.-D.B., ORR, A.G., PAULSON, D.R. and VAN TOL, J. Global diversity of dragonflies (Odonata) in freshwater. In: E.V. BALIAN, C. LÉVÊQUE, H. SEGERS and K. MARTENS. Freshwater animal diversity assessment. Dordrecht: Springer, 2007, pp. 351-363.

KARR, J.R., FAUSCH, K.D., ANGERMEIER, P.L., YANT, P.R. and SCHLOSSER, I.J. Assessing biological integrity in running waters: A Method and its Rationale [online]. Champaign: Illinois Natural History Survey, 1986, Special Publication, 5. [viewed 05 Sep. 2019]. Available from: https://www.researchgate. net/publication/245507787_Assessing_biological_ integrity_in_running_waters_A_method_and_its_ rationale.

KAUFMANN, P.R., LEVINE, P., ROBISON, E.G., SEELIGER, C., PECK, D.V., AGENCY, U.S.E.P., BRANCH, R.E., DIVISION, W.E., HEALTH, N. and EFFECTS, E. Quantifying Physical Habitat in Wadeable Stream. EPA/620/R-99/003. Washington, DC: U.S. Environmental Protection Agency, National Health and Environmental Effects Research Laboratory, Western Ecology Division, 1999.

KOMPIER, T. A guide to the Dragonflies and Damselfies of the Serra dos Orgaos, South-eastern Brazil. Northam, UK: Regua Publications, 2015.

LANDEIRO, V.L., HAMADA, N., GODOY, B.S. and MELO, A.S. Effects of litter patch area on macroinvertebrate assemblage structure and leaf breakdown in Central Amazonian streams. Hydrobiologia, 2010, 649(1), 355-363. http://dx.doi. org/10.1007/s10750-010-0278-8.

LENCIONI, F. A. A. Damselflies of Brazil, an illustrated identification guide: II - Coenagrionidae families. São Paulo: All Print Editora, 2006.

LENCIONI, F.A.A. Damselfies of Brazil, an illustrated identification guide: I-Non-Coenagrionidae families. São Paulo: All Print Editora, 2005.

LIMA, G.P., PEIXOTO NETO, C.A.A., AMARAL, Y.T. and SIQUEIRA, G.M. Biogeographical Characterization of the Maranhense Eastern Mesoregion (Brazil). Journal of Geospatial Modelling, 2016, 1(1), 1. http://dx.doi.org/10.22615/jgm-1.15809. 
MAY, M.L. Thermoregulation and Adaptation to Temperature in Dragonflies (Odonata: Anisoptera). Ecological Monographs, 1976, 46(1), 1-32. http:// dx.doi.org/10.2307/1942392.

MENDES, T.P., CABETTE, H.S.R. and JUEN, L. Setting boundaries: Environmental and spatial effects on Odonata larvae distribution (Insecta). Anais da Academia Brasileira de Ciências, 2015, 87(1), 239-248. http://dx.doi.org/10.1590/00013765201520130477 . PMid:25806986.

MIGUEL, T.B., OLIVEIRA-JUNIOR, J.M.B., LIGEIRO, R. and JUEN, L. Odonata (Insecta) as a tool for the biomonitoring of environmental quality. Ecological Indicators, 2017, 81, 555-566. http:// dx.doi.org/10.1016/j.ecolind.2017.06.010.

MONTEIRO-JÚNIOR, C. S.M., JUEN, L. and HAMADA, N. Analysis of urban impacts on aquatic habitats in the central Amazon basin: adult odonates as bioindicators of environmental quality. Ecological Indicators, 2015, 48, 303-311. http://dx.doi. org/10.1016/j.ecolind.2014.08.021.

MONTEIRO-JÚNIOR, C.S., COUCEIRO, S.R.M., HAMADA, N. and JUEN, L. Effect of vegetation removal for road building on richness and composition of Odonata communities in Amazonia, Brazil. International Journal of Odonatology, 2013, 16(2), 135-144. http://dx.doi.org/10.1080/13887 890.2013.764798.

MONTEIRO-JÚNIOR, C.S., JUEN, L. and HAMADA, N. Effects of urbanization on stream habitats and associated adult dragonfly and damselfly communities in central Brazilian Amazonia. Landscape and Urban Planning, 2014, 127, 28-40. http://dx.doi. org/10.1016/j.landurbplan.2014.03.006.

NESSIMIAN, J.L., VENTICINQUE, E.M., ZUANON, J., DE MARCO JUNIOR, P., GORDO, M., FIDELIS, L., D'ARC BATISTA, J. and JUEN, L. Land use, habitat integrity, and aquatic insect assemblages in Central Amazonian streams. Hydrobiologia, 2008, 614(1), 117-131. http://dx.doi. org/10.1007/s10750-008-9441-x.

NETO, E.B. (2015). Desenvolvimento urbano. In I. G. SOUSA, J. M. VIANNA, \& R. L. MENESES (Eds.), Cartografias invisiveis: saberes e sentires de Caxias. Caxias: Academia Caxiense de Letras.

NEWBOLD, T., HUDSON, L.N., HILL, S.L.L., CONTU, S., LYSENKO, I., SENIOR, R.A., BÖRGER, L., BENNETT, D.J., CHOIMES, A., COlleN, B., DAY, J., DE PALMA, A., DÍAZ, S., ECHEVERRIA-LONDOÑO, S., EDGAR, M.J., FELDMAN, A., GARON, M., HARRISON, M.L.K., ALHUSSEINI, T., INGRAM, D.J., ITESCU, Y., KATTGE, J., KEMP, V., KIRKPATRICK, L., KLEYER, M., CORREIA, D.L., MARTIN, C.D., MEIRI, S., NOVOSOLOV, M., PAN, Y., PHILLIPS, H.R., PURVES, D.W., ROBINSON, A., SIMPSON, J.,
TUCK, S.L., WEIHER, E., WHITE, H.J., EWERS, R.M., MACE, G.M., SCHARLEMANN, J.P. and PURVIS, A. Global effects of land use on local terrestrial biodiversity. Nature, 2015, 520(7545), 45-50. http://dx.doi.org/10.1038/nature14324. PMid:25832402.

NÓBREGA, C.C. and DE MARCO JUNIOR, P. Unprotecting the rare species: A niche-based gap analysis for odonates in a core Cerrado area. Diversity \& Distributions, 2011, 17(3), 491-505. http://dx.doi. org/10.1111/j.1472-4642.2011.00749.x.

OLIVEIRA-JUNIOR, J.M.B., JUNIOR, P.D.M., DIAS-SILVA, K., LEITÃO, R.P., LEAL, C.G., POMPEU, P.S., GARDNER, T.A., HUGHES, R.M. and JUEN, L. Effects of human disturbance and riparian conditions on Odonata (Insecta) assemblages in eastern Amazon basin streams. Limnologica, 2017, 66, 31-39. http://dx.doi. org/10.1016/j.limno.2017.04.007.

OLIVEIRA-JUNIOR, J.M.B., SHIMANO, Y., GARDNER, T.A., HUGHES, R.M., DE MARCO JÚNIOR, P. and JUEN, L. Neotropical dragonflies (I nsecta: $\mathrm{O}$ donata) as indicators of ecological condition of small streams in the eastern A mazon. Austral Ecology, 2015, 40(6), 733-744. http://dx.doi. org/10.1111/aec.12242.

OLIVER, I., DORROUGH, J., DOHERTY, H. and ANDREW, N.R. Additive and synergistic effects of land cover, land use and climate on insect biodiversity. Landscape Ecology, 2016, 31(10), 2415-2431. http:// dx.doi.org/10.1007/s10980-016-0411-9.

PECK, D.V., LAZORCHAK, J.M. and KLEMM, D.J. Environmental Monitoring and Assessment ProgramSurface Waters: Western Pilot Study Field Operations Manual for Wadeable Streams. Corvallis, OR: National Health and Environmental Effects Research Laboratory [and] National Exposure Research Laboratory, Office of Research and Development, US Environmental Protection Agency, 2002.

PEREIRA, L.R., CABETTE, H.S.R. and JUEN, L. Trichoptera as bioindicators of habitat integrity in the Pindaíba river basin, Mato Grosso (Central Brazil). Annales de Limnologie-International Journal of Limnology, 2012, 48(3), 295-302. http://dx.doi. org/10.1051/limn/2012018.

PESSACQ, P., MUZÓN, J. and VON ELLENRIEDER, N. Description of the last larval instar of Acanthagrion ablutum Calvert (Zygoptera: Coenagrionidae). Odonatologica, 2005, 34(1), 73-76.

PHILLIPS, H.R.P., NEWBOLD, T. and PURVIS, A. Land-use effects on local biodiversity in tropical forests vary between continents. Biodiversity and Conservation, 2017, 26(9), 2251-2270. http://dx.doi. org/10.1007/s10531-017-1356-2. PMid:32025108.

RFOUNDATIONFORSTATISTICALCOMPUTING (2015). R. Development Core Team: R: A language and 
environment for statistical computing (No. 2015). Vienna: R Foundation for Statistical Computing.

RODRIGUES, M.E., DE OLIVEIRA ROQUE, F., QUINTERO, J.M.O., DE CASTRO PENA, J.C., DE SOUSA, D.C. and DE MARCO JUNIOR, P. Nonlinear responses in damselfly community along a gradient of habitat loss in a savanna landscape. Biological Conservation, 2016, 194, 113-120. http:// dx.doi.org/10.1016/j.biocon.2015.12.001.

RODRIGUES, M.E., MOURA, E.B. and ROQUE, F.O. Dragonflies as indicators of the environmental conditions of veredas in a region of central-western Brazil. Oecologia Australis, 2018, 23(4), 969-978. http://dx.doi.org/10.4257/oeco.2019.2304.20.

RODRIGUES, M.E., ROQUE, F.D.O., GUILLERMOFERREIRA, R., SAITO, V.S. and SAMWAYS, M.J. Egg- laying traits reflect shifts in dragonfly assemblages in response to different amount of tropical forest cover. Insect Conservation and Diversity, 2019, 12(3), 231-240. http://dx.doi.org/10.1111/ icad.12319.

SCOTT, S.E., PRAY, C.L., NOWLIN, W.H. and ZHANG, Y. Effects of native and invasive species on stream ecosystem functioning. Aquatic Sciences, 2012, 74(4), 793-808. http://dx.doi.org/10.1007/ s00027-012-0263-6.

SHAIEK, M., ZAABOUB, N., AYAS, D., ALVES MARTINS, M.V. and ROMDHANE, M.S. Crabs as bioindicators of trace element accumulation in Mediterranean Lagoon (Bizerte Lagoon, Tunisia). Journal of Sedimentary Environments, 2018, 3(1), 135. http://dx.doi.org/10.12957/jse.2018.32950.

SIQUEIRA, R.M.B. and HENRY-SILVA, G.G. A bacia hidrográfica como unidade de estudo e o funcionamento dos ecossistemas fluviais. Boletim Da Associação Brasileira de Limnologia,, 2011, 39(2), $1-15$.
SILVA, D. J, \& CONCEIÇÃO, G. M. (2011). Rio Itapecuru: caracterização geoambiental e socioambiental, município de Caxias, Maranháo, Brasil. Scientia Plena, 7(1), 1-26.

SOUZA, H.M.L., CABETTE, H.S.R. and JUEN, L. Baetidae (Insecta, Ephemeroptera) em córregos do cerrado matogrossense sob diferentes níveis de preservação ambiental. Iheringia. Série Zoologia, 2011, 101(3), 181-190. http://dx.doi.org/10.1590/ S0073-47212011000200005.

STRAHLER, A.N. Quantitative analysis of watershed geomorphology. Eos (Washington, D.C.), 1957, 38(6), 913-920.

TRUEMAN, J. W. H., \& ROWE, R. J. Odonata. Dragonflies and Damselflies. Version 16 October 2009. 2009 [viewed 03 Mar. 2020]. Available from: http:// tolweb.org/Odonata/8266/2009.10.16 in The Tree of Life Web Project, http://tolweb.org/.

VERAS, D.S., CASTRO, E.R., LUSTOSA, G.S., DE AZEVÊDO, C.A.S. and JUEN, L. Evaluating the habitat integrity index as a potential surrogate for monitoring the water quality of streams in the cerrado-caatinga ecotone in northern Brazil. Environmental Monitoring and Assessment, 2019, 191(9), 562. http://dx.doi.org/10.1007/s10661-0197667-x. PMid:31410581.

VILELA, D.S., FERREIRA, R.G. and DEL-CLARO, $\mathrm{K}$. The Odonata community of a Brazilian vereda: seasonal patterns, species diversity and rarity in a palm swamp environment. Bioscience Journal, 2016, 32(2), 486-495. http://dx.doi.org/10.14393/BJv32n2a2016-30491.

Received: 19 August 2019

Accepted: 26 May 2020

Associate Editors: Victor Satoru Saito. 